\title{
Melangkah Perlahan, Bekerja Berjejaring
}

\author{
Ismail Suardi Wekke \\ Dewan Pendidikan Kabupaten Maros \\ Email: iswekke@gmail.com
}

Bapak/Ibu, Saudara-saudari...

Assalamu Alaikum Warahmatullahi Wabarakatuh.

Semoga kita semua tetap sehat wal'afiat. Alhamdulillah, tadi malam saya tiba di Jakarta. Sekarang sementara beraktivitas di Jakarta, untuk satu pekan ke depan.

Sejak pelantikan 29 November 2021, alhamdulillah Dewan Pendidikan Kabupaten Maros telah bergerak dan juga turut dalam mengaktualisasi partisipasi masyarakat dalam pendidikan.

Begitu pula Rapat Kerja (27 Desember 2021) dan Orientasi (14 Januari 2022) menjadi kesempatan mengkonsolidasi kepengurusan, dan pada saat yang sama menyatukan langkah untuk menuntaskan masa amanah dalam kurun lima tahun.

Ini semua terlaksana berkat soliditas dan juga kesamaan gerak langkah kita dalam mewujudkan visi Kabupaten maros sebagaimana yang tertuang dalam RPJMD Kab Maros. Komposisi keanggotaan Dewan Pendidikan Kabupaten Maros, bisa saling melengkapi dan juga dengan kehadiran, partisipasi, serta kepemimpinan ketua Dewan Pendidikan Kabupaten Maros.

Untuk Desember-Januari, alhamdulillah telah terlaksana:

1) Pertemuan dengan Pusat Pengabdian Masyarakat UIN Alauddin Makassar untuk pelaksanaan KKN di empat kecamatan (29 Desember 2021);

2) Pertemuan dengan SES Jerman untuk memfasilitasi pendidikan keolahragaan dan juga pendidikan vokasi (8 Januari 2022);

3) Pelatihan Penyusunan Proposal kerja sama dengan LPPM STAI DDI Maros (15 Januari 2022);

4) Rangkaian Diklat Profesi Guru melalui Penulisan KTI (16 Januari 2022);

Belum lagi, rangkaian dalam partisipasi dengan kegiatan yang mengundang Dewan Pendidikan Kabupaten Maros untuk turut serta hadir.

Dalam tiga sampai empat pekan ke depan, kami sekadar bisa aktif melalui kegiatan-kegiatan online. Untuk itu, akan dilaksanakan aktivitas dengan menggunakan zoom.

Mendukung penyebaran informasi ke stakeholder pendidikan di Maros, ada dua grup yang terbentuk. Pertama, tim kecil dukungan sekretariat Dewan Pendidikan Kabupaten Maros di aplikasi WhatsApp. Kemudian juga ada grup telegram untuk sosialisasi informasi.

Untuk mendukung kerja-kerja teknis Dewan Pendidikan Kabupaten Maros, saya mengusulkan untuk adanya kemitraan dengan lembaga dan institusi. Bisa dengan perguruan tinggi, begitu pula dengan lembaga kepemudaan, atau sekolah/madrasah.

Saya beruntung bisa berdiskusi dengan dekan FKIP UMMA, semoga beliau bisa memberikan dukungan teknis bagi perjalanan ke depan Dewan Pendidikan Kabupaten Maros. Juga saya sudah berdikusi dengan pengurus Yayasan Insan Intelektual Indonesia. Sehingga kita bisa bergerak bersama-sama. 
Insya Allah esok akan dilaksanakan diskusi dalam kaitan program "Penyediaan Kesempatan Belajar di Luar Negeri". Saya sudah mohon bantuan ustadz Rahmat untuk mencarikan satu alumni STAI DDI untuk kuliah ke Malaysia. Beasiswa dari UCYP Malaysia, dimana saya menjadi adjunct professor sejak 2018.

Pengumuman beasiswa ini akan diserahkan insya Allah, jikalau acara MoU terlaksana februari mendatang insya Allah. Supaya bisa menjadi pengumuman aktualisasi kerja-kerja Dewan Pendidikan Kabupaten Maros.

Absensi acara yang kemaren (Diklat Penulisan KTI) sudah ada. Mohon bantuan ustadz Rahmat untuk membuatkan sertifikat eletronik dan mengirimkannya melalui email kepada peserta yang mengisi absen.

Sementara itu, bagi peserta yang mengikuti rangkaian secara lengkap, akan kita berikan sertifikat dengan tanda tangan Bapak Kepala Dinas Pendidikan dan Kebudayaan Kabupaten Maros.

Agenda juga berikutnya, diklat perpustakaan yang akan terlaksana, minimal sekali dalam satu bulan. Sehingga akan ada 12 diklat selama setahun insya Allah.

Sekali lagi, terima kasih Bapak/Ibu, Saudara-saudari atas kebersamaan.

Salam sehat selalu...

Wassalamu alaikum warahmatullahi wabarakatuh. 